\title{
Muslim-Christian Relationships in Indonesian Reform Era Within The Framework of Democracy: Case Study of Bandung, Bekasi and Bogor (1998-2015)
}

\author{
Angel Damayanti \\ Faculty of Social and Political Sciences \\ Universitas Kristen Indonesia \\ Jakarta - Indonesia \\ angel.damayanti@uki.ac.id
}

\begin{abstract}
A relatively peaceful and harmonious relationship between Muslims and Christians in Indonesia has been dotted by religious intolerance and worship restrictions in the form of churches destruction, banned and closed. The majority of restrictions happened in West Java Province, mostly in Bandung, Bekasi and Bogor regions where this research use them as a case study. Ironically, the majority of restriction occurred in the Reformasi era, where the political system should have promoted human rights and practices of the decentralized system. Against this background, this thesis seeks to find out the cases of worship restriction in reform era and how a democratic government deals with such restriction. To answer the questions, this research utilizes qualitative methodology particularly the case studies, to ensure the comprehensiveness of its data sources and analyzes. By employing theories of democracy and democratization, decentralization, and human rights, this study finds that MuslimsChristians relationship since the beginning of their encounter in Indonesia has been spoiled by reciprocal threat perception regarding the suspicion of Christianization vis a vis the suspicion of the establishment of the Islamic state.
\end{abstract}

Keywords-Muslims-Christians relationship, Indonesian Reform era, democracy, religious intolerance, worship restrictions.

\section{INTRODUCTION}

An ancient Greek philosopher, Aristotle (350 BC), had put an important foundation of democracy when he said that democracy coexists with the enactment of liberty and equality, which then becomes the central element of human rights. The conception of democracy keeps developing, and now many countries in the world claim themselves to become democratic states. Influenced by western political scientists [1], state leaders believe that democratic political system is an essential basis for the enforcement, promotion and protection of human rights, including the religious freedom and right to exercise its worships. Nonetheless, this article performs that the changing of the political system in Indonesia towards more democratic worsened the Muslims-Christians relationship as it resulted in significant numbers of worship restriction in several areas of Indonesia, particularly in West Java province.

It is true that international community and national authorities in Indonesia have placed a comprehensive and legal basis for human rights promotion and protection including for the religious freedom. As reported by some non-government organizations, both local and international, the implementation remains problematic. Apparently, there is a gap between the policy made by central governments and its implementation by local governments. This article therefore deeply elaborates the issue of the antagonistic relationship between the majority Muslims and minority Christians in Indonesia, which is endorsed by the local government and followed by worship restrictions in the era of democracy.

Interestingly, worship restrictions in Indonesia come together with the democratic transition in the country. The political system changing from an authoritarian into a more democratic state in the late 1990s has raised hopes to its people that they would have enjoyed a greater human rights promotion and protection, including the freedom of thought, union, speech, religion and its practices of worship. This study finds that a democratic system in Indonesia worsened the MuslimChristian relationship and resulted in religious intolerance and worship restriction in particular areas such as Bandung, Bekasi and Bogor, which are endorsed by the local government. 
Using the qualitative research design, particularly the case study, this article emphasizes the importance of social and political context for understanding the current phenomenon and encourages the researcher to have close involvement in social and/or political fields to gain information and important data [2]. This study uses both primary and secondary data to support its analysis. They are collected from interviews with religious leaders and government officers as well as from various literature, reports documents, and database collected by other scholars and/or researchers, such as Persekutuan Gereja-gereja di Indonesia (PGI), Forum Komunikasi Kristiani Jakarta (FKKJ), Wahid Institute (WI) and Setara Institute (SI). This article will be organized in five subchapters, started by the background and followed by the historical description of the dynamic relationships between Indonesian Muslims and Christians. Afterwards this article will elaborate how a democratic transition worsened Muslims-Christians relationship and contributed to worship restrictions by looking at cases in Bandung, Bekasi and Bogor, and eventually, this article will be concluded by recommendations.

\section{THE DYNAMIC OF MUSLIM- CHRISTIAN RELATIONSHIPS IN INDONESIA}

Christianity entered Indonesia brought by Germany, Portuguese and Dutch missionaries when Islam reached its peak in most of Indonesia in the $16^{\text {th }}$ century. The evangelism practised by Western missionaries was difficult to apply to the local Muslims people, particularly in Java and Sumatra, rejected the

new religion. They often described Christian missionaries and their followers as infidels or devils and the religion is always associated with the colonialists and perceived as "a religion of the colonialists" [3]. This situation caused Christianization only succeeded in North Sumatera and Eastern part of Indonesia such as East Nusa Tenggara, Ambon, Manado and Papua, who remained practised the local beliefs as well as animism and dynamism [4].

One thing that we need to note that evangelists from different countries conveyed different teachings and practices of Christianity in Indonesia [5], as there are Catholic, Lutheran, Calvinist, Anglican, Mennonite, Baptist, Methodist, Pentecostalism and Charismatic denominations spread and then developed all over Indonesia. Such divergent accordingly explains the logics behind the establishment of a great number of churches within the Christian community.
Similarly, the Indonesian Muslims are not one united actor as they follow very diverse streams embracing from traditional, modern, puritan, extreme, fundamentalist and radical. The majority of them, if not all, follow Sunni, and most of them join Nahdlatul Ulema (NU) as well as Muhammadiyah, the biggest Islamic Organizations in Indonesia which claim to have more than 40 million and 30 millions members respectively.

Although Muslims and Christians first encounter was sensitively marked with rejection and negative perception, the feelings of nationalism and the desire to expel Dutch colonialists as their common enemy eventually united them. In the second Youth Congress, 27-28 October 1928, youths from Java, Sumatera, Betawi (Jakarta), and Celebes or Sulawesi, who are Muslims, and Christian youths from North Sumatera, Ambon, and Chinese descendants, came together and declared themselves as one nation, regardless their religions. This Muslims-Christians relationship was considered positive until Indonesia gained its independence in August 1945.

Couple months before the Indonesian Independence Declaration, there was a debate between nationalist groups and religious groups, mostly from Islamic groups, regarding the form of the state and the ideology that the country would use. Religious groups from Masyumi, Nahdlatul Ulama, Partai Syarikat Islam Indonesia, and Islamic Party called PERTI, insisted on establishing an Islamic State, as they believed that most of the Indonesian people embraced Islam as their religion. Yet leaders from nationalists, such as Soekarno And Hatta prevailed to convince them to establish the state of Indonesia in a secular form of Republic concerning all religions with the consideration of the diversity of ethnics, religions and races in Indonesia. They eventually agreed to establish a state with Republic system and accepted Pancasila as the ideology instead of Islamic laws [6].

This positive relationship between Muslims and Christians relatively lasted until the end of New Order Era under Soeharto's regime. According to Mujiburrahman [7], Soeharto successfully increased the economic welfare and the national security with a strong military power, which was used to against any domestic disturbances including that came from religious groups. With his ability to stabilize the national situation as well as

1 Sukarno expressed his political view about the form of the newborn state, Indonesia, in Public Lecture in University of Indonesia, 7 May 1953, titled, “Negara Nasional dan Cita-Cita Islam." 
regional security, there was no significant tension between Muslims and Christians. The increasing numbers of Christian followers have provoked suspicious from Muslims towards Christianization programs conducted by missionary organizations in Indonesia and from abroad. This situation then developed into a tension between Muslims and Christians during New Order Era [8].

The tension deteriorated at the end of Soeharto's regime and when political system in Indonesia finally changed into a more democratic regime in mid-1998. Started with a church destruction in Gereja Misi Injili in Pontianak in March 1996 and then followed by Situbondo cases, in which more than 15 churches were destroyed in the same time, the situation between Muslims and Christians got worsened. There were altogether 145 churches had been destructed and burnt only in 2 years, (1996-May 1998) [9]. The tension apparently came from both groups, resulted from their movements and activities.

On the one hand, Suharto points out the aggressive Christianity missionary activities using churches for converting massive Muslims to Christians as a trigger to their tension [10]. The missionary program usually comes in the form of giving basic needs, sponsorship for education and free medical treatments for the needy people. The missionary activities are allegedly supported by the rising of Pentecostalism and Charismatic (Neo-Pentecostalism) Christian movements in Indonesia, brought by the US missionaries in the late 1970s [11]. They delivered their teachings using advance methods, such as making revival services and healing ministry ${ }^{2}$ Withdrawing a lot of people to join the ministry.

As a result of Christianity missionary, the number of Christian adherents has grown and become the religion with a second largest number of followers in Indonesia, after Islam. In 2010, the Central Bureau of statistic (BPS) as cited in 2015 Annual Report of Indonesian Ministry of Religion Affairs, records that Islam

Revival services and healing ministry are usually conducted by the denomination of Pentecostal and Charismatic Churches in a broad place, such as in convention halls, hotels or at open space, with massive numbers of people involved and well-prepared program. The organizers sometimes also publish the revival services information through radio, TV, banners and flyers to invite a lot of people who are in faith degradation, experience severe sickness and/or other bad situation to come and to have a revival in their life or to be healed from their sickness. This method can be very attractive to bring a lot of people, mostly Christians and other religion adherents, to come and to experience what they claim as a revival and healing movement. At the end of the service, the priests usually invite those who are not believers yet to come and to be prayed so they can accept Christianity as their religion. adhered by the majority of Indonesia people, numbers to 207.176 .162 or $87,21 \%$ of the total population, followed by Protestant that has 16.528.513 people or 6,96\%; Roman Catholic with 6.907.873 adherents or 2,91\%; Hinduism with 4.012 .116 or $1,69 \%$; Buddhism shares 1.703.254 people or $0,72 \%$ and Confucianism with 117.091 followers or $0,05 \%$. Other beliefs have 299.617 followers or $0,5 \%$.

Although Christianity (Protestant and Catholic) ranks second largest population in Indonesia, according to National Census by Central Statistic Agency in 2010, the number of its followers significantly grows from $2.8 \%$ in 1933 to $7.39 \%$ in $1971,8.83 \%$ in 1980 , $9.6 \%$ in 1990 , and $9.87 \%$. The increasing number of Christians is accordingly followed by a rapid growth of its worship places. This is not to mention the dissension of churches denomination influencing their followers to establish their churches based on denominations. The prohibition from the leaders of certain churches to their congregations to join churches other than their denominations, which they claim to have different teachings and doctrines, provokes the establishment of many new churches based on denominations.

The increasing numbers of Christian followers and the obscurity numbers of Christians' worship places to a greater extent raise concern and are perceived threat by some Muslims. They have been critical of so-called Christianization program conducted by the churches and missionary organizations from Indonesia and abroad [12]. Such Christianization program provokes insecurity feeling of the hardline groups, and they react accordingly to what they considered as Christian provocation. They perceive that they need to defend their faith and reject any efforts to convert their Muslim friends, including through the services that are conducted at a Christian's home covered by birthday celebration [13].

On the other hand, Solahudin focuses on the rise of political Islam that initially happened in Iran, which then provoked Islamic group in Indonesia to conduct similar ways to topple Soeharto's regime. This situation created fear towards Christians, as they perceived the Muslims were establishing an Islamic State in Indonesia and this would harm their life and interests in Indonesia. Over the years Christians perceive that radical Muslims have been devoting their efforts to establish an Islamic State in Indonesia, which is rooted in the establishment of Darul Islam in 1948 [14].

The history of Islamic State started when Kartosuwirjo had a disappointment with the 
legal government under Soekarno and perceived that nationalist party could not fulfil the aspiration of majority Muslims in Indonesia. His mission was then to establish an Islamic State supported by Daud Beureuh in Aceh and Kahar Muzakar in South Sulawesi. Kartosuwirjo's Islamic State covered West Java, Central Java, partly of Aceh and South Sulawesi. Although this movement was eventually defeated in 1962, the ideology of Islamic State remains embraced by Kartosuwirjo's followers and their descendants up to now. The activities of Jemaah Islamiyah Indonesia (JII) from the 1990s to mid-2000s to stifle the legal government and attack other religious communities, which are then followed by its affiliations currently, performed the aspirations of such ideology [15].

\section{DEMOCRATIC TRANSITION AND WORSHIP RESTRICTION}

Democratic transition in Indonesia, which should have promoted peaceful and freedom, has apparently been spotted by violence amongst and within internal religious followers, coupled with religious intolerance. Report of National Commission of Human Rights (Komnas HAM) in 2015 records that the abuse against the right of religious freedom and faith practices numbered to 95, in which 61 incidences or about $60 \%$ took the forms of banning, blocking, destroying worship places and stopping religious activities. Such restrictions not only targeted at Christian communities but also to other minority Muslim communities such as Ahmadiyah and Shi'ite and the community of other religious adherents. This fact proves that even until 2015, the rights to practice religious belief and faith in Indonesia has yet guaranteed, regardless of constitutional mandate, and worship restrictions remain to exist [16].

The process of democratization in Indonesia, which has developed since 1998, brings two major changes including the promotion of freedom regarding union, expression and religion as well as changing from the centralistic types of government to the decentralization or regional autonomy. First, with regards to the freedom of speech, expression and union, Indonesian people may perceive it as a stimulation to establish nongovernmental organizations to perform a significant role of civil society in democratic states. The establishment of civil societies, on the one hand, contributes positively to the democratic political system of Indonesia. But, on the other hand, it leaves a bulk of problems at the social, political and cultural spheres, including the inter-faiths relationship. As confirmed by Bahtiar Effendy, rather than responding to the Indonesian democratic transition, some social and political movements emerged as instruments to actively express and uphold radical ideology using the religious symbol. This accordingly creates religious intolerance perpetrated by some militant and/or hardline groups towards other religious groups [17].

Secondly, the central mission of the political transformation in Indonesia is delegating government affairs more to local government, while certain government functions such as fiscal and monetary, foreign affairs, judicial security, defence and religion remain the authority of central government. Decentralization is vital in democratic system. In the $6^{\text {th }}$ Global Forum on Reinventing Government organized by South Korea and the United Nations on 27 May 2005 state leaders agreed on "Seoul Declaration on Participatory and Transparent Governance" which confirmed that "good governance requires an appropriate level of decentralization, innovation and development of local government.” Such system makes local administration works more effectively.

Although religion is part of central government's functions, in managing the establishment of worship places as part of religious affairs in Indonesia, the central government represented by Ministry of Religious Affairs and Ministry of Home Affairs issued joint decree called Peraturan Bersama Menteri (PBM) No. 8 and 9 in 2006. The core of this decree is delegating the authority of the establishment of worship places to the local/regional leader to ensure the order and the smoothness of the religious and belief practices. However, the implementation of this joint decree (PBM) has created at least four critical issues. First, PBM/2006 puts an uneven considering on the role of the head of local government in promoting the religious and worship freedom. As the principle of the establishment of worship, places are now seen more from the perspective of order and security, not from the perspective of promoting religious freedom as one of the fundamental human rights.

Secondly, PBM No. 8 and 9/2006 is in some ways are believed to limit religious freedom more than promote or protect it. It requires the signatories from 90 users and consent from 60 members of the community surrounding the location (article 14). Thirdly, PBM No. 8 and 9/2006, which initially aimed at reducing discrimination, in its implementation creates otherwise. Formerly 
the establishment of worship places needs no special permit. It required a regular permit just like the one in the establishment of a regular building which needed no 60 consent signatures of people living surroundings. The role of the government was simply to check the feasibility, the ownership and the security of the building. The enactment of PBM/2006 inspires people whether to agree or disagree with the establishment of the church and might provoke reciprocal protests. Human Right Watch (HRW) confirms that PBM/2006 created "unnecessary restriction" for building worship places [18]. And fourthly, the $\mathrm{PBM} / 2006$ fails to solve the problem of worship restrictions at the grass-roots level. Difficulties in obtaining the permit for the establishment of worship places resume the target of violence and intimidation.

With regards to worship restriction, the International Religious Freedom Act of 1998, published in the $105^{\text {th }}$ US Congress and the UN Resolution No A/RES/51/93 regarding Elimination of all Forms of Religious Intolerance (Art. 4), has explained the terminology from the behavior, activities and perpetrators. This article mainly uses the definition by looking at two dimensions; first is the policies and activities that launched and committed by the government which restrict and prohibit certain religious groups to conduct their worship activities, and second is all efforts and intolerant acts perpetrated by radical groups to stop minority religious groups' worship activities, such as threatening, intimidating, destroying, burning, stoning and exploding their worship places that is allowed, tolerated and/or supported by the local government and security apparatus. The supports from local government can be seen through policies launched and/or activities to let the violence happened as well as to support the restriction against Christians' activities and worship after they received the report or protest from mass and/or hardline groups.

As far as religious intolerance materialized in church restrictions is concerned, data collected from Persekutuan Gereja-gereja di Indonesia (PGI) or the Council of Churches in Indonesia, Forum Komunikasi Kristiani Jakarta (FKKJ), Wahid Institute (WI) and Setara Institute (SI) discloses that during Indonesian Reform Era, from June 1998 to Dec 2015, worship restrictions across areas in Indonesia in terms of church destruction, closing, and worship banning have been experienced by at least 643 churches from various denominations. This numbers excluded the worship places destruction in Poso, Palu and Maluku during socio-religious conflicts from late 1990s to mid 2000 in which 192 churches and 28 mosques were destroyed and burnt, as well as the incidences of terrorist attack such as the Christmas' eve bombing in 2000 in which 24 churches were exploded [19].

From a statistical point of view, Indonesian Christians suffered 35,6 worship and churches restriction each year from 1998 to 2015. The following graphic shows that majority restrictions took place in 1998 with 81 churches were restricted. It is then consecutively followed in 2011 with 78 churches, 2010 with 65 churches, 2002 with 52 churches, 2004 and 2013 with 51 churches each, 2012 with 47 churches, 2005 with 39 churches, 1999 and 2001 with 31 churches each, and 2007 with 22 churches. Worship restrictions took place less than 20 in 2002, 2003, 2006, 2008 and 2009 with 10, 9, 17, 14, and 15 churches each. Seen from the periodical sequence, Church restrictions in Indonesia took into two forms; the first type of restriction targeted to the established churches, the second one is targeted to the churches before their establishment [20]. 


\section{FIGURE 1. CHURCH RESTRICTIONS IN INDONESIA FROM JUNE 1998 TO DEC 2015}

Source: Reports from PGI, FKKJ, SI, and WI churches, West Nusa Tenggara province with 29 churches, South Sulawesi province with 23 churches, Yogyakarta with 20 churches, North Sumatera and Riau provinces with 13 churches

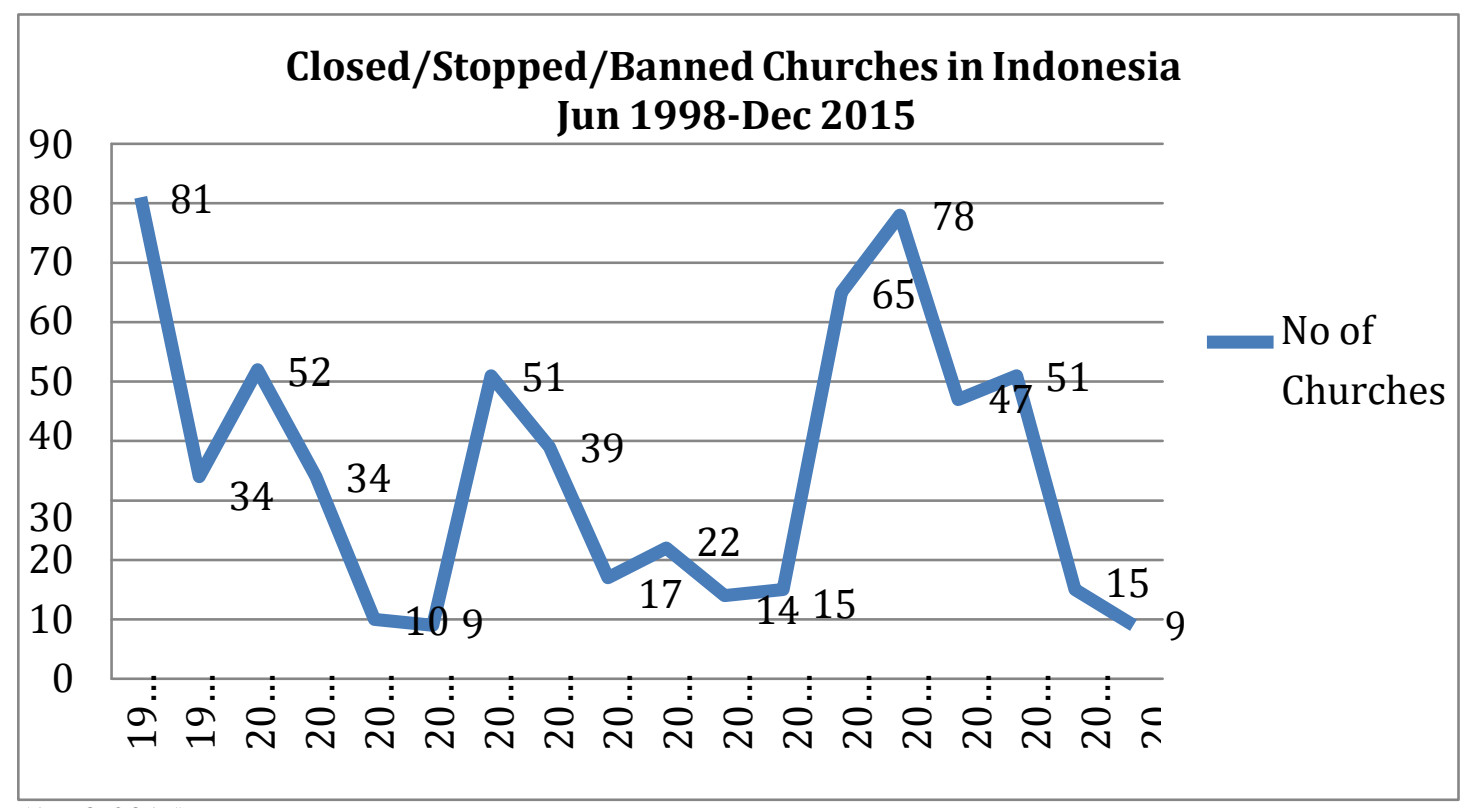

(1998-2015)

During Old Order era (August 1945March 1967) under President Soekarno, for about 22 years only two churches that were attacked, and no churches were threatened or banned. The number of worship restrictions increased during New Order era (April 1967May 1998) under President Soeharto, for about 32 years 444 churches were attacked, two churches were threatened, and only ten churches were banned. Of the incidences, 145 churches were attacked, or $33 \%$ of incidences occurred in the last two years of Soeharto's regime (1996-May 1998). The number of worship restrictions significantly increased in Reform Era (June 1998-Dec 2015). As 643 churches have been restricted in 17 years, with 238 churches were attacked, destroyed, stoned or exploded, 111 churches were threatened/rejected, 53 churches were sealed, and 241 churches were closed or banned [21].

The above-mentioned worship restrictions have taken place in 20 out of 34 provincial areas throughout Indonesia, with 105 district areas (Kabupaten) and City areas (Kota). Majority incidences took place in West Java with 270 churches were restricted, where Bekasi experienced majority cases with 89 churches were restricted, Bandung with 81 churches and Bogor with 18 churches. It is then followed consecutively by Central Java province with 63 churches were restricted, DKI Jakarta province with 57 churches, Aceh province with 46 churches, Banten province with 43 churches, East Java province with 36 each, Central Sulawesi province with 10 churches, Bengkulu and Lampung provinces with 4 churches each, South Kalimantan provinces with 3 churches, East Kalimantan, Jambi, South Sumatera and Maluku provinces with 2 churches each, and West Sumatera province with 1 church each.

\section{WORSHIP RESTRICTION IN}

BANDUNG, BEKASI AND BOGOR

At the surface, religious tolerance in Bandung seems fine. The moderate Muslim organizations such as Nahdlatul Ulama and Christian Community sometimes hold forums to maintain tolerance. In such meetings, they sought to reach a mutual understanding or consensus for common interest. The majority of Bandung government officers feel that religious tolerance within Muslims community and between Muslims and non-Muslims' life in Bandung runs well. Bandung people who are educated are quite supportive of such tolerant life [22]. Nonetheless, beneath, the negative perception, attitude and behavior between Muslim and Christian communities, which lead to violence and religious intolerance, remain existed.

In a more detail explanation, $73 \%$ of 81 worship restriction incidences in Bandung occurred in the form of fiercely closing the worship places, which are most likely due to misuse of residents and/or office building and no permits. $16 \%$ of the restrictions manifested in the forms of threat or intimidation such as rejection from residents, $7 \%$ of the incidents 
are in the form of attacking, destroying, burning, or exploding the worship places, and $4 \%$ is in the form of sealing. $38 \%$ of the worship restriction targeted to residential houses, which have been used for worship places and more than $50 \%$ restrictions took the terms of closing and sealing the churches which they consider "illegal” or have no permit from local government and banning the worship done in such churches [23].

There are multi causes explaining such restrictions. The first and foremost is the difficulties and the failure in obtaining a permit for building the church. It, therefore, makes sense that the majority of restriction actors in Bandung involved local government apparatus, as their restriction action is the implementation of law enforcement against the church constructions, which obtained no permit. In some incidences, local government apparatus is represented by the head of sub-district, head of the village and local police units for order and security or also known as Satpol PP. Interestingly, in doing such worship restriction, local government officers received support from local mass and hardline groups such as Front Pembela Islam (FPI), Alliance of AntiApostate Movements or Aliansi Gerakan Anti Pemurtadan (AGAP), and Islamic Reformist Movement or Gerakan Islam Reformis (GARIS) [24]. Out of 81 church restrictions in Bandung, 54 cases caused by local government's action such as reluctant of giving letter of permit and their instruction to close or ban churches with or without support from local people and hardline groups, 28 restrictions were supported by local Muslim mass and residents, and 25 restrictions were supported by militant/hardline groups, including FPI, AGAP, and GARIS.

Similarly, Bekasi experienced 89 incidences of worship restrictions during 19982015. Different from incidences in Bandung, 28 incidences in Bekasi took the term of church closing and or banning. The number of violent incidences in term of church attacks, destroy and destruction are quiet significant with 16 incidences, compared to those of Bandung, which only occurred six times. Intimidation and threats by local people and radical mass were experienced by 31 churches, and church sealed committed to at least 14 churches. Cases in Bekasi show striking figures on the involvement of radical groups include Islamic Defender Front (FPI), Forum Majelis Peduli Umat (FMPU), Forum Umat Islam, Bekasi (FUI), Forum Islam Bersatu (FIB) and Forum Anti Pemurtadan (FAP). The figure is similar to that of Bandung where radical mass was involved in 29 of 89 incidences, while the local government represented by Bekasi city mayor, Satpol PP, local police, head of sub-district and head of sub-neighbourhood were behind 30 incidences. The rest, 41 incidences involved ordinary Muslims, but received support from FPI and FUI.

A striking example of this is the case of HKBP Filadelfia. The church management successfully collected 259 signatures of agreement from people living in the surrounding locations. The number of signatures is even more than that required by PBM 2006 (60 signatures). Unfortunately, the HKBP did not even receive consent from the local ministry of religious affairs and the Interreligious Harmony Forum (FKUB). The HKBP Filadelfia then appealed the case. The Provincial State Administration Court (PTUN) in Bandung and the Supreme Court in Jakarta won the case. Controversially the Bekasi District Head (Bupati) at that time, Saadudin, persisted in rejecting to issue the construction permit of HKBP church [25].

Even when the Supreme Court verdict had won HKBP Filadelphia appeal, the local government persisted that the verdict could not be executed due to threat of conflicts with the protesters. The case proved that the local government failed to obey the central government's decision as well as to provide protection and to promote order in local society. The protester groups supported by the government offered the HKBP Filadelphia for relocation [26]. Until 2012, Filadelphia could not worship at their church building. Hardline groups blocked Filadelphia members to enter the church building and made them worship in the parking location of the church [27].

A different case applies in the case of Santa Clara Catholic Church and HKBP Manseng in North Bekasi. Although these two churches have got a letter of permission since 2015 and the major of Bekasi City, Rahmat Effendi has justified the construction of these two churches, the residents supported by Islamic movements such as Forum Umat Islam, Bekasi and Forum Anti Pemurtadan (Anti Apostate Forum), remained rejected the constructions. Even, when the hardliners forced the local leaders to stop the worship activities conducted by these two churches, Bekasi City major insisted on allowing both churches to commit their services. Effendi's persistence on this issue has provoked a contention between the local leaders and radical groups in Bekasi. Yet, it brought him to gain an award from National Commissioner on Human Rights (Komnas HAM) in 2016 [28]. 
In Bogor, 11 of the 18 church restrictions are closed/banned due to the failure of getting building construction permit (IMB), four of which were closed/banned due to misuse of the home store as a church, 6 others were attacked or destroyed, and another church was rejected and intimidated by residents. Thirteen incidences of worship restriction in Bogor were conducted by ordinary mass Muslims and/or local residents, 10 of which are supported by local leaders and local government. Again the issue of the failure in obtaining the construction permit form local government motivated them to the actions. Six restrictions were conducted by FPI and Forum Umat Islam (FUI), a new actor, which only was active in worship restrictions issue in Bogor, but not in Bekasi and Bandung.

A striking example is the case of GKI Yasmin Bogor construction, as it has become a political issue and was under the wide media spotlight and attention by the international community. GKI Yasmin has fulfilled all requirements for the construction of a Church such as getting signatures of agreement from members of community living surrounding it. In 2008 the local government of Bogor, particularly the office of City Plan and Park froze the permit of worship building construction, without clear reasoning, but simply reviewing the permit. In fact, GKI had bought the land and had got a permit for construction. When GKI management staff reported the case to National Commission of Human Rights, the officer of City Plan and Park of Bogor local government argues that the freezing was simply to temporarily cool down the pressure from Muslim Activists Forum (FORKAMI) [29].

FORKAMI mobilized massive demonstration to reject the construction of the church located on Kyai Haji Abdullah Bin Nuh Street, a name taken from a late Muslim legendary leader. They argued, as agreed by Bogor Mayor Diani Budiarto, that "It would not be good to build a Church on a street which uses the name of a legendary Muslim leader," a senseless reason which defeats legal argument [30]. With this in mind, Bogor Mayor has made legal constraints in the building of worship place. The Ombudsman, which backed up the verdict of the Supreme Court, ordered the Bogor Mayor and West Java Governor Ahmad Heryawan to obey the verdict and asked Minister of Home Affairs to supervise its implementation. Yet, Bogor Mayor Budiarto persisted not to obey the Ombudsman recommendation but offered to relocate the construction, in which GKI Yasmin management rejected [31].

\section{CONCLUSION AND RECOMMENDATION}

The negative interconnection between Muslims and Christians in Indonesia has started since their first encounter with reciprocal threat perception becomes the dominant explanation. While Muslims accused Christians of continuing Christianization mission, Christians suspected Muslims community remains installed an agenda on establishing Islamic states. The negative perception between these two communities turned into worship restriction when Indonesia experienced political system transition into a more democratic country in the late 1990s. Ironically, the freedom of union, speech and expression coupled with the implementation of decentralization has become the central issue to explain such problem. The creation of Islamic socio-movements with radical ideology such as FPI, FUI, AGAP and GARIS on one hand and Christianization program conducted by Pentecostalism and Charismatic church denominations, on the other hand, has provoked the religious intolerance between the two communities.

Also, with the delegation of authority from central to local government on the worship places establishment through joint decree No. 8 and 9/2006, religious intolerance becomes worship restriction that violates the freedom of religion, particularly in West Java province. Surprisingly, the perpetrators of the restriction include local government officers such as the head of sub-district, head of district, major and even governor, police unit for security and orders who share the majority of actors, followed by hardline Islamic groups and head of neighborhood. The involvement of government officers in the worship restriction is manifested in banning church activities and/or withdrawing the letter of permit for the church building's construction, which leads to further destructive activities by Islamic hardliner groups. Severely, the government failed to provide protection, assistance, and facilitation for Christian congregations to practice their worship activities. Of the restricted churches, striking cases such as HKBP Filadelfia, Santa Clara Catholic Church and HKBP Manseng church in Bekasi, coupled with GKI Yasmin and Santo Johaness Baptista in Bogor, has been covered widely under media spotlights and received international concerns.

There are four recommendations that can be delivered from this article. First, Indonesian central government needs to monitor the work of local governments and security apparatus in 
maintaining and upholding the religious tolerance in their areas of authorities. Secondly, the central government also needs to encourage the role of Harmony Forum for Religious Communities or also known as Forum Kerukunan Umat Beragama (FKUB) in helping the local government to uphold the religious tolerance and resolve any problem emerged from intra and inter-faiths tension and/or conflict. Thirdly, the government needs to monitor the enhancement of numbers of worship places by rationalizing the numbers of acknowledged religions' adherents without limiting their religious freedom. Both central and local government, through Ministry of Religious Affairs, should make an arrangement of church denominations including their church building, especially for Christian communities to avoid negative perception both from other church's denominations and other religion adherents. The last but not the least, an education for religious leaders to deliver the message of peace and tolerance towards their congregations as well as to respect other religion teachings is vital. Hence, the government, supported with FKUB (Forum of Inter-Religious Harmony), needs to encourage religious leaders to have a mutual understanding about other religions' values and traditions and to respect the differences, particularly between Muslim and Christian communities.

\section{REFERENCES}

[1] Beetham, David, Democracy and Human Rights, Cambridge: Polity Press, 2000; Smith, Karen E., European Union Foreign Policy in a Changing World, Cambridge: Polity, 2003; Sikkink, Kathryn, "The Power of Principled Ideas: Human Rights Policies in the United States and Europe," in Ideas and Foreign Policy: Beliefs, Institutions and Political Change, ed. Judith Goldstein and Robert O. Keohane. New York: Cornell University Press, 1993; Norman, J. "Human Rights and Democracy: Conceptualization and Application in Palestine," 1993 [Online] [Accessed 12 $2^{\text {th }}$ September 2014] Available from World Wide Web: http://www.multaqa.org/pdfs/HumanRights \&Democracy.pdf

[2] Blaikie, Norman, Designing Social Research: The Logic of Anticipation, $2^{\text {nd }}$ Edition, Cambridge: Polity Press, 2010.

[3] Wanandi, Jusuf, "Islam in Indonesia: Its History, Development and Future Challenges,” in Asia-Pacific Review, 9, (2), 2002, pp. 104-112; Mak Lau-Fong, Islamization in Southeast Asia, Taipei: Asia
Pacific Research Program, 2002, pp. 223228;

[4] Aritonang, Jan S., Sejarah Perjumpaan Kristen dan Islam di Indonesia, Jakarta: BPK Gunung Mulia, 2004; Steenbrink, Karel, Dutch Colonialism and Indonesian Islam: Contacts and Conflicts 1596-1950, Netherlands: Rodopi B.V, 2006.

[5] Goh, Robbie B.H., Christianity in Southeast Asia, Singapore: ISEAS, 2005; Aritonang, Jan, Berbagai Aliran di dalam Gereja dan di Sekitar Gereja, Jakarta: BPK Gunung Mulia, 2016.

[6] Solahudin, NII Sampai JII: Salafy Jihadisme di Indonesia, Jakarta: Komunitas Bambu, 2011.

[7] Mujiburrahman, Muslim-Christian Relations in Indonesia's New Order, Leiden: Amsterdam University Press, 2006.

[8] Sudarto, H., Konflik Islam-Kristen: Menguak Akar Masalah Hubungan Antar Umat Beragama di Indonesia, Semarang: PT Pustaka Rizki Putra, 1999; Fahardian, Charles E., Christianity, Islam and Nationalism in Indonesia, New York: Routledge, 2005.

[9] Forum Komunikasi Kristiani Jakarta, Annual Reports on Religious Intolerance, Jakarta, 1996-1998.

[10] Sudarto, H., Konflik Islam-Kristen: Menguak Akar Masalah Hubungan Antar Umat Beragama di Indonesia, Semarang: PT Pustaka Rizki Putra, 1999.

[11] Aritonang, Jan, Berbagai Aliran di dalam Gereja dan di Sekitar Gereja, Jakarta: BPK Gunung Mulia, 2016.

[12] Mujiburrahman, Muslim-Christian Relations in Indonesia's New Order, Leiden: Amsterdam University Press, 2006; Fahardian, Charles E., Christianity, Islam and Nationalism in Indonesia, New York: Routledge, 2005; Aritonang, Jan S., Sejarah Perjumpaan Kristen dan Islam di Indonesia, Jakarta: BPK Gunung Mulia, 2004; Arifianto, Alexander R., "Explaining the Cause of Muslim-Christian Conflicts in Indonesia: Tracing the Origins of Kristenisasi and Islamisasi," in ChristianMuslim Relations, 20, (1), pp. 73-89, 2009.

[13] Interview with Hidayat Bustaman, Chairman of West Java Forum for InterReligious Harmony (FKUB), Bandung, 6 Feb 2016.

[14] Solahudin, NII Sampai JII: Salafy Jihadisme di Indonesia, Jakarta: Komunitas Bambu, 2011, pp. 7-47.

[15] Fealy, Greg, "Half a Century of Violent Jihad in Indonesia: A Historical and Ideological comparison of Darul Islam and Jemaah Islamiyah," in Marika Vicziany and David Wright-Neville (eds). Islamic Terrorism in Indonesia: Myths and Realities, Victoria: Monash University 
Press, 2005; Solahudin, NII Sampai JII: Salafy Jihadisme di Indonesia, Jakarta: Komunitas Bambu, 2011, pp. 7-47.

[16] Komnas HAM RI, Laporan Akhir Tahun Kebebasan Beragama/Berkeyakinan Tahun 2015, (2015 End Year Report of Religious Freedom), [Online] [Accessed 25 $5^{\text {th }}$ March 2016] Available from World Wide Web: https://www.komnasham.go.id/files/201509 08-pelapor-khusus-kebebasan-beragama\$DFNW.pdf

[17] Effendy, Bahtiar, Islam and the State in Indonesia, Singapore: ISEAS, 2003, pp. 217-218.

[18] Human Rights Watch, In Religion's Name: Abuses against Religious Minorities in Indonesia, 2013, p. 32 [Online] [Accessed $20^{\text {th }}$ November 2016] Available from World Wide Web: https://www.hrw.org/report/2013/02/28/reli gions-name/abuses-against-religiousminorities-indonesia

[19] Kampschulte, Theodor, Situasi HAM di Indonesia: Kebebasan Beragama dan Aksi Kekerasan, Postfach: Internationales Katholicsches Missioswerk e.v Fachstelle Menschenrechte, 2001; Forum Komunikasi Kristiani Jakarta, Annual Reports on Religious Intolerance, Jakarta, 1998-2004; and Budi Gunawan, Terorisme: Mitos \& Konspirasi, Jakarta: Forum Media Utama, 2006, pp. 114-116.

[20] PGI, Annual Reports on Religious Intolerance, 2004-2011; Forum Komunikasi Kristiani Jakarta (FKKJ), Annual Reports on Religious Intolerance, Jakarta, 19982015; Setara Institute (SI), “Laporan Kebebasan Beragama dan Berkeyakinan 2007-2011; Setara Institute, "Report Summary: Tolerant City Index,” 2015; The Wahid Institute (WI), Annual Report of Religious Freedom in Indonesia, 2009-2015; The Wahid Institute, Ringkasan Eksekutif Laporan Tahunan Kemerdekaan Beragama dan Berkeyakinan (KBB) di Indonesia, Jakarta: The Wahid Institute, 2016.

[21] Reports from PGI, FKKJ, SI and WI, 19982015

[22] Interview with Dr. Nurrohman; a committee of Jakatarub (Jaringan Kerja Antar Umat Beragama/Network for Inter-religious Cooperation), Bandung City, Vice Chairman of Bashul Masail, Nadhatul Ulama, West Java and professor in Faculty of Syariah, UIN Bandung, West Java, Bandung, 16 January 2016.

[23] Reports from PGI, FKKJ, SI and WI, 19982015

[24] Reports from PGI, FKKJ, SI and WI, 19982015

[25] Human Rights Watch, In Religion's Name: Abuses against Religious Minorities in Indonesia, 2013, p. 53.
[26] Human Rights Watch, In Religion's Name: Abuses against Religious Minorities in Indonesia, 2013, p. 53-54.

[27] Lembaga Studi dan Advokasi Masyarakat (ELSAM), Laporan Situasi HAM di Indonesia Tahun 2012 [Online] [Accessed $20^{\text {th }}$ November 2016] Available from World Wide Web: http://perpustakaan.elsam.or.id/index.php?p =show_detail\&id=14437\&keywords=tahun +peningkatan

[28] "Keteguhan Walikota Bekasi Pertahankan Gereja Santa Clara" [Online] [Accessed 20 $0^{\text {th }}$ April 2017] Available from World Wide Web:

http://megapolitan.kompas.com/read/2017/0 3/25/08254701/keteguhan.wali.kota.bekasi. pertahankan.gereja.santa.clara

[29] Komnas HAM RI, (2016), Laporan Akhir Tahun Kebebasan Beragama/Berkeyakinan Tahun 2016 (2016 End Year Report of Religious Freedom), [Online] [Accessed $9^{\text {th }}$ April 2017] Available from World Wide Web:

https://www.komnasham.go.id/files/201703 24-laporan-tahunan-kebebasan-beragama\$IUKH.pdf

[30] Human Rights Watch, In Religion's Name: Abuses against Religious Minorities in Indonesia, 2013, p. 52.

[31] Human Rights Watch, In Religion's Name: Abuses against Religious Minorities in Indonesia, 2013, p. 53. 